\title{
Effect of Irrigation Levels and Frequencies on Yield, Quality and Water Use Efficiency of Capsicum Grown under Protected Conditions
}

\author{
Ramesh Kumar' ${ }^{1}$, Prabal Kumari ${ }^{2}$ and Sandeep Kumar ${ }^{3}$ \\ ${ }^{1}$ Dept. of Vegetable Science, Dr. Y.S. Parmar University of Horticulture and Forestry, Solan, Nauni, H.P. (173 230), India \\ ${ }^{2}$ Dept. of Horticulture, Chotta Shimla, Navbahar, Shimla, H.P. (171 002), India \\ ${ }^{3}$ ICAR-Indian Agricultural Research Institute Regional Station, Katrain, Kullu, H.P. (175 129), India
}

\section{Article History}

Manuscript No. AR1702b

Received in $20^{\text {th }}$ September, 2016

Received in revised form $20^{\text {th }}$ November, 2016

Accepted in final form $6^{\text {th }}$ December, 2016

\section{Correspondence to}

${ }^{*} E$-mail: sandeepkdhatwalia@gmail.com

\section{Keywords}

Capsicum, irrigation, yield, TSS, ascorbic acid, root rot

\begin{abstract}
The present investigation was carried out at Experimental Research Farm of the Department of Vegetable Science, Dr. Y.S. Parmar University of Horticulture and Forestry, Nauni, Solan (HP), India during spring-summer seasons of year 2010 and 2011 to standardize the irrigation scheduling for improving capsicum yield, quality and water use efficiency under protected conditions. The experiment was laid down in RCBD with seven treatments having three irrigation depths, two intervals and a farmers practice. The data were recorded on fruit length $(\mathrm{cm})$, fruit breadth $(\mathrm{cm})$, average fruit weight $(\mathrm{g})$, number of fruits plant ${ }^{-1}$, total biomass production $(\mathrm{g} /$ plant), yield plot ${ }^{-1}(\mathrm{~kg})$, total soluble solids $\left({ }^{\circ} \mathrm{B}\right)$, ascorbic acid $\left(\mathrm{mg} 100 \mathrm{~g}^{-1}\right)$, root rot incidence (\%), water productivity $\left(\mathrm{kg} \mathrm{m}^{-2} \mathrm{~cm}^{-1}\right)$ and soil moisture (\%). The perusal of the pooled data revealed that different levels and frequencies of irrigation produced significant differences with regards to different traits under study. The treatment with $0.50 \mathrm{~cm}$ of irrigation at alternate day resulted in maximum fruit breadth $(6.53$ $\mathrm{cm})$, average fruit weight $(95.20 \mathrm{~g})$, number of fruits plant ${ }^{-1}(18.26)$, total biomass production (165.38 $\left.\mathrm{g} \mathrm{plant}^{-1}\right)$ and highest economic yield plot $\left(36.17 \mathrm{~kg} \mathrm{plot}^{-1}\right)$ and along with moderate water productivity $\left(0.25 \mathrm{~kg} \mathrm{~m}^{-2} \mathrm{~cm}^{-1}\right)$, may be recommended for commercial cultivation of capsicum in the hilly regions under naturally ventilated polyhouses. However, the treatment with $0.25 \mathrm{~cm}$ of irrigation at alternate day recorded maximum water productivity $\left(0.43 \mathrm{~kg} \mathrm{~m}^{-2} \mathrm{~cm}^{-1}\right)$ and total soluble solids $(5.30 \%)$ with moderate yield $\left(30.58 \mathrm{~kg} \mathrm{plot}^{-1}\right)$ and lowest root rot incidence $(2.76 \%)$, may be suggested for the high water scare areas for the successful cultivation of capsicum under protected conditions.
\end{abstract}

\section{Introduction}

Capsicum (Capsicum annuum L. var. grossum Sendt) is one of the highly remunerative vegetables cultivated throughout the world (Roopa and Kumar, 2014). Today, it has attained a status of high value crop in India because of its delicacy and pleasant flavour coupled with rich content of ascorbic acid and other vitamins and minerals (Kurubetta and Patil, 2009). Despite its economic importance, growers are not in a position to produce good quality capsicum along with high productivity due to various biotic (pest and diseases), abiotic (rainfall, temperature, relative humidity and light intensity) stresses under open field conditions (Manna and Ray, 2015). Due to erratic behaviour of weather, the crops grown in open field are often exposed to fluctuating levels of rainfall, temperature, humidity, wind flow etc., which ultimately affect the crop productivity adversely
(Ochigbo and Haris, 1989). Besides this, in the hilly states like Himachal Pradesh limited availability of land for cultivation hampers the vegetable production.

Recently, polyhouse cultivation of capsicum is proving to be a very remunerative venture to the greenhouse growers as it fetches maximum returns in the markets as well as its benefit: cost ratio is also very high, since it is being grown in the cost effective naturally ventilated polyhouses (Ghosal and Das, 2012). The high market price is attributed to the heavy demand from the urban consumers. However, the supply is inadequate due to the low productivity of the crop (Muthukrishnan et al., 1986). The cultivation of crops under protected structures increases irrigation water use efficiency and produces yields that are about five to ten times greater than in the open field conditions (Vox et al., 2010). Hence, to obtain a good quality produce and production during off season, there is a need to 
cultivate capsicum under protected condition.

Among the various production aspects under protected conditions, availability of optimum soil moisture throughout the growing season is an important factor in any crop production programme, because both excess as well as scarcity of water affects total crop yields (Dagdelen et al., 2004). The irrigation system facilitate uniform soil moisture distribution in root zone continuously at an optimum level and leading to higher and better quality crop yields (Hardeman et al., 2000). In recent, damaging effect of climate change on global food security has assumed a frightening dimension leading to food shortages due to water scarcity especially in developing nations (Akinbile and Yusoff, 2011). In the hilly regions of the country, perennial sources of water are scare and farmers are mainly depended upon the kharif and spring season rainfall for their crop requirements, which is erratic in behavior. This leads to moisture stress during critical growth periods. Moreover, irrigation facilities in the hilly state like Himachal Pradesh are very limited due to undulating topography. Therefore, need for efficient irrigation scheduling for improving capsicum productivity has became imperative. Keeping above facts in view, the present study, therefore, was undertaken to standardize the water requirement under drip irrigation system of capsicum for higher yield, improved quality and water use efficiency under protected conditions.

\section{Materials and Methods}

\subsection{Experimental site and layout plan}

The present investigation was carried out in a naturally ventilated polyhouse at Experimental Research Farm of the Department of Vegetable Science, Dr. YS Parmar University of Horticulture and Forestry, Nauni, Solan (HP), India, during spring-summer seasons of year 2010 and 2011. There were seven treatments comprising of three irrigation depths, two intervals and a farmers practice i.e., $\mathrm{T}_{1}: 0.25 \mathrm{~cm}$ irrigation daily; $\mathrm{T}_{2}: 0.25 \mathrm{~cm}$ irrigation at alternate day; $\mathrm{T}_{3}: 0.50 \mathrm{~cm}$ irrigation daily; $\mathrm{T}_{4}: 0.50 \mathrm{~cm}$ irrigation at alternate day; $\mathrm{T}_{5}$ : $0.75 \mathrm{~cm}$ irrigation daily; $\mathrm{T}_{6}: 0.75 \mathrm{~cm}$ irrigation at alternate day; $\mathrm{T}_{7}$ : Farmer's practice (Two times irrigation week ${ }^{-1}$ till the establishment of seedlings and later on $1-1.5 \mathrm{~cm}$ irrigation with canes/pipes twice a week). Seeds of capsicum hybrid 'Bharat' were sown during the month of February, 2010 and 2011 in well prepared nursery beds and 30 days old seedlings were transplanted in the polyhouse. The experiment was laid down in Randomized Complete Block Design (RCBD) and 21 seedlings in each treatment combination were transplanted at a distance of $45 \times 30 \mathrm{~cm}^{2}\left(1350 \mathrm{~cm}^{2}\right)$ in well prepared plots of $1.35 \times 2.10 \mathrm{~m}^{2}\left(2.835 \mathrm{~m}^{2}\right)$ size and were replicated four times in four different blocks. Each block was separated by $0.5 \mathrm{~m}$ wide bund and within blocks each treatment was arranged $45 \mathrm{~cm}$ apart to avoid lateral movement of water along the treatment.
In each plot, three drip lines were installed for each row. Each emitter served water requirement for single plant placed at $30 \mathrm{~cm}$ distance. The duration of operation of drip system for different treatments of irrigation was controlled by a flow control valve. After establishment of seedlings, irrigation water was applied through drip irrigation system as per treatments assigned during the complete growing season. The amount of water actually applied by the way of drip irrigation system was based on evapo-transpiration basis (climatological approach). The amount of water discharged per minute was calculated to fix the time for supplying the desired quantity of water to each plot as per the treatments assigned. For applying 0.25 , 0.50 and $0.75 \mathrm{~cm}$ water, drippers flow was run approximately for $15-17,30-35$ and 40-45 minutes, respectively. All the recommended package of practices and plant protection measures standardized for ployhouses were followed time to time to ensure a healthy crop stand (Anonymous, 2010).

\subsection{Data recording and statistical analysis}

The observations pertaining to different traits under study were recorded on 10 randomly selected plants from each treatment plot per replication. The fruit length $(\mathrm{cm})$ and breadth $(\mathrm{cm})$ of ten randomly selected fruits from each treatment at second picking was measured with the help of a digital Vernier Caliper and average was calculated. The average fruit weight (g) was calculated by dividing the total marketble yield of the selected plants with the total number of marketable fruits. Number of fruits harvested from selected plants at each picking were counted and averaged to work out the number of fruits plant ${ }^{-1}$. Total dry weight of plant excluding roots was taken to calculate the total biomass production $\left(\mathrm{g} \mathrm{plant}^{-1}\right)$. Total weight of the fruits harvested from selected plants was added and mean value was worked out for the yield plot $^{-1}(\mathrm{~kg})$. Total soluble solids $\left({ }^{\circ} \mathrm{B}\right)$ content of five randomly selected fruits from each replication was estimated with the help of hand refractrometer and mean value was worked out. Ascorbic acid content (mg $100 \mathrm{~g}^{-1}$ ) of fruits was determined as per the method suggested by Ranganna (1986). At the end of season, all plants were uprooted and per cent root rot incidence was calculated out of total plants planted in a plot. Water use efficiency (WUE) or water productivity (WP) was computed by dividing yield with total quantity of water applied and expressed as $\mathrm{kg} \mathrm{m}^{-2}$ $\mathrm{cm}^{-1}$. Soil moisture content was determined gravimetrically in irrigated plots up to $15.0 \mathrm{~cm}$ depth $(0-7.5$ and $7.5-15.0 \mathrm{~cm})$ at 15 days interval during the period of experimentation. The known mass of moist soil sample was dried in an oven at 105 ${ }^{\circ} \mathrm{C}$. The mass of wet soil, dry soil and container was taken and the per cent moisture present was calculated as follows: Soil moisture content $(\%)=\frac{(\mathrm{Y}-\mathrm{Z})}{(\mathrm{Z}-\mathrm{X})} \times 100$

Where, $\mathrm{X}=$ Weight of empty moisture box $(\mathrm{g})$; $\mathrm{Y}=$ Wet soil 
weight with box (g); Z=Weight of dry soil (g); (Y-Z)=Moisture content in soil; $(\mathrm{Z}-\mathrm{X})=$ Weight of oven dried soil.

All the data pertaining to yield and quality traits were analyzed as per randomized complete block design (RCBD) suggested by Gomez and Gomez (1984).

\section{Results and Discussion}

The analysis of variance revealed the significant effect of irrigation levels and frequencies on yield and quality parameters under study (Table 1), which have been described and discussed as follows:

\subsection{Fruit length $(\mathrm{cm})$}

In the present investigation, fruit length was significantly affected by all the treatment combinations. Pooled analysis of

\subsection{Average fruit weight $(g)$}

Fruit weight has direct effect on yield and this is a character which appeals to the consumers. It is evident from the pooled data of 2010 and 2011 that average fruit weight was significantly influenced by variation in levels and frequencies of irrigation during the period of study (Table 2). Among all treatments, maximum fruit weight was recorded $(95.20 \mathrm{~g})$ with $\mathrm{T}_{4}$. Similarly, Gupta et al. (2010) had also reported maximum fruit weight in capsicum with moderate irrigation level $(80 \%$ of pan evapo-transpiration) through drip irrigation as compared to $100 \%$ surface irrigation. In the mean while, minimum average fruit weight was recorded in $\mathrm{T}_{2}(79.32 \mathrm{~g})$ due to scarcity of water. Smittle et al. (1994); Sezen et al. (2011) revealed that fruit weight is closely associated with a lack of soil water in the root zone; when soil water deficit in root zone increases, there

\begin{tabular}{lcccccccccc}
\hline \multicolumn{10}{c}{ Table 1: Analysis of variance for various horticultural and quality traits in capsicum after pooled analysis of 2010 and 2011} \\
\hline
\end{tabular}

*Significant at $(p=0.05)$ level of significance

data (2010 and 2011) showed that maximum fruit length (8.57 $\mathrm{cm})$ was recorded in $T_{5}$ and minimum fruit length $(7.77 \mathrm{~cm})$ was observed in $\mathrm{T}_{1}$ (Table 2). In general, a gradual increase in fruit length was noticed up to a certain level $\left(\mathrm{T}_{5}\right)$ and decreased further. It is revealed that highest fruit length in $T_{5}$ resulted due to availability of appropriate moisture content at fruit development stage. Ertek et al. (2007) had also reported that lack of water reduces the fruit length in green capsicum.

\subsection{Fruit breadth (cm)}

Significant differences were observed among different levels and frequencies of irrigation for fruit breadth after pooled analysis of 2011 and 2012 (Table 2). Maximum fruit breadth of $6.53 \mathrm{~cm}$ was recorded in $\mathrm{T}_{4}$ and minimum of $5.90 \mathrm{~cm}$ fruit breadth was recorded in $\mathrm{T}_{1}$. In line with present investigations, Gupta et al. (2010) had also reported maximum fruit breadth in capsicum with moderate irrigation level ( $80 \%$ of pan evapotranspiration) as compared to $100 \%$ of pan evapo-transpioration through drip irrigation and $100 \%$ surface irrigation. Similarly, Sezen et al. (2011) also revealed decrease in fruit breadth by water stress in capsicum. is loss in turgidity leading to reduction in average fruit weight.

\subsection{No. of fruits plant ${ }^{1}$}

Number of fruits plant ${ }^{-1}$ is an important character, since it ultimately reflects the total marketable yield. Pooled data of both the years (2010 and 2011) as presented in table 2 showed that maximum numbers of fruits (18.26) were recorded in $\mathrm{T}_{4}$. This might be due to better micro-climate responsible for efficient water utilization at early crop growth stages, which ultimately lead to more number of flowers and hence more number of fruits in $T_{4}$. On the other hand, minimum (14.47) numbers of fruits plant ${ }^{-1}$ were observed in $T_{1}$. This might be attributed to reduced number of flowers produced rather than poor fruit set (Masuda and Hayashi, 1957). It reveals that both the excess as well as less supply of water has resulted into less number of fruits plant ${ }^{-1}$. Hence, controlled irrigation is essential for having higher fruit number in capsicum as this crop is sensitive to both excess and under irrigations (Anonymous, 2009). Earlier workers like Chartzoulakis et al. (1997) had reported that numbers of fruits plant ${ }^{-1}$ were affected significantly by amount of irrigation water applied, 
Table 2: Effect of irrigation levels and frequencies on yield and quality traits in capsicum under protected conditions (Pooled data of 2010 and 2011)

\begin{tabular}{lccccccccc}
\hline Traits & $\begin{array}{c}\text { Fruit } \\
\text { length } \\
(\mathrm{cm})\end{array}$ & $\begin{array}{c}\text { Fruit } \\
\text { breadth } \\
(\mathrm{cm})\end{array}$ & $\begin{array}{c}\text { Average } \\
\text { fruit } \\
\text { weight }(\mathrm{g})\end{array}$ & $\begin{array}{c}\text { No. of } \\
\text { fruits } \\
\text { plant }{ }^{-1}\end{array}$ & $\begin{array}{c}\text { Total biomass } \\
\text { production } \\
\left(\mathrm{g} \text { plant }{ }^{-1}\right)\end{array}$ & $\begin{array}{c}\text { Yield } \\
\text { plot } \\
(\mathrm{kg})\end{array}$ & $\begin{array}{c}\text { Total } \\
\text { soluble } \\
\text { solids }\left({ }^{\circ} \mathrm{B}\right)\end{array}$ & $\begin{array}{c}\text { Ascorbic } \\
\text { acid } \\
\left(\mathrm{mg} 100 \mathrm{~g}^{-1}\right)\end{array}$ & $\begin{array}{c}\text { Root rot } \\
\text { incidence } \\
(\%)\end{array}$ \\
\hline $\mathrm{T}_{1}$ & 7.77 & 5.90 & 81.36 & 14.47 & 113.71 & 24.78 & 4.94 & 122.91 & $2.85(1.33)^{*}$ \\
$\mathrm{~T}_{2}$ & 8.28 & 6.06 & 79.32 & 15.65 & 116.26 & 30.58 & 5.30 & 122.63 & $2.76(1.17)$ \\
$\mathrm{T}_{3}$ & 8.21 & 6.34 & 94.51 & 17.90 & 141.80 & 35.37 & 4.78 & 124.33 & $9.59(3.08)$ \\
$\mathrm{T}_{4}$ & 8.52 & 6.53 & 95.20 & 18.26 & 165.38 & 36.17 & 5.13 & 124.02 & $10.66(3.26)$ \\
$\mathrm{T}_{5}$ & 8.57 & 6.21 & 93.66 & 17.18 & 162.89 & 33.77 & 4.09 & 125.12 & $18.12(4.25)$ \\
$\mathrm{T}_{6}$ & 8.14 & 6.08 & 92.76 & 16.77 & 152.58 & 32.67 & 4.18 & 126.19 & $13.89(3.72)$ \\
$\mathrm{T}_{7}$ & 8.00 & 6.13 & 83.65 & 15.69 & 154.48 & 26.58 & 5.22 & 126.11 & $7.74(2.75)$ \\
\hline $\mathrm{CD}(p=0.05)$ & 0.50 & 0.27 & 3.54 & 1.52 & 4.22 & 2.36 & 0.28 & 1.84 & 0.69 \\
\hline
\end{tabular}

$\mathrm{T}_{1}: 0.25 \mathrm{~cm}$ irrigation daily; $\mathrm{T}_{2}: 0.25 \mathrm{~cm}$ irrigation at alternate day; $\mathrm{T}_{3}: 0.50 \mathrm{~cm}$ irrigation daily; $\mathrm{T}_{4}: 0.50 \mathrm{~cm}$ irrigation at alternate day; $\mathrm{T}_{5}: 0.75 \mathrm{~cm}$ irrigation daily; $\mathrm{T}_{6}: 0.75 \mathrm{~cm}$ irrigation at alternate day; $\mathrm{T}_{7}:$ Farmer's practice (Two times irrigation week $^{-1}$ till the establishment of seedlings and later on 1-1.5 cm irrigation with canes/pipes twice a week); ${ }^{*}$ Figures in the parentheses are square root transformed values

whereas Ertek et al. (2007) revealed that number of fruits plant $^{-1}$ goes on increasing with the increase in irrigation levels and frequencies in capsicum, which contradicts the results of present investigations. This might be due to the difference in soil, climate and type of protected structure used during the investigations.

\subsection{Total biomass production ( $g$ plant ${ }^{-1}$ )}

Pooled analysis of 2010 and 2011 revealed that the effects of levels and frequencies of irrigation were significant (Table 2). Maximum and significantly higher biomass (165.38 g) was observed with moderate irrigation level viz., $\mathrm{T}_{4}$, which might be due to the higher plant height in $\mathrm{T}_{4}$. Hedge (1988) had reported that irrigation at a soil matric potential of -45 to $-65 \mathrm{kPa}$ results in significantly higher dry matter production as compared to very high or low frequency of irrigation at -25 or $-85 \mathrm{kPa}$. Similarly, Gupta et al. (2010) resulted in highest dry matter content in capsicum by $80 \%$ evapo-transpiration through drip irrigation as compared to $60 \%$ and $100 \%$ evapotranspiration. In the mean while, minimum biomass was observed in $\mathrm{T}_{1}(113.71 \mathrm{~g})$, which may be due to water stress conditions during crop growth period.

\subsection{Yield plot ${ }^{-1}(\mathrm{~kg})$}

Fruit yield plot $^{-1}$ is the resultant of yield contributing traits of the plant especially number of fruits plant ${ }^{-1}$ and average fruit weight. A perusal of pooled data (2010 and 2011) in the (Table 2) indicated that levels and frequencies of irrigation had significant effect on yield plot $^{-1}$. Maximum and significantly higher yield $(36.17 \mathrm{~kg})$ was observed with moderate irrigation level viz., $\mathrm{T}_{4}(0.50 \mathrm{~cm}$ of irrigation daily), which might be due to the higher average fruit weight and more fruit no. in the treatment $\mathrm{T}_{4}$. It is revealed that optimum soil moisture availability in root zone of the crop results in higher fruit yield in capsicum (Gupta et al., 2010). Results of present investigations are in line with (Singh et al., 2011), who had also observed higher fruit yield in capsicum with moderate irrigation treatment viz., 0.8 potential evapo-transpiration (PET) as compared to 1.0 and 0.6 PET. In the mean while, minimum yield of $24.78 \mathrm{~kg}$ was recorded in the treatment $\mathrm{T}_{1}$, which might be due to water stress conditions during crop growth period. (Ertek et al., 2007) had reported that the scarcity of water reduces the fruit yield in green capsicum. In the mean while, Hegde (1988) had observed that fruit yield goes on increasing when capsicum is subjected to -25 to -65 $\mathrm{kPa}$ irrigation regime and reduced when imposed to either high or low water stress.

\subsection{Total soluble solids $\left({ }^{\circ} \mathrm{B}\right)$}

Total soluble solids (TSS) content in the fruit is an important quality parameter. A perusal of the pooled data (2010 and 2011) revealed that different levels and frequencies of irrigation produced significant differences with regards to TSS content in the fruits (Table 2). The maximum TSS of $5.30^{\circ} \mathrm{B}$ was recorded in the treatment $\mathrm{T}_{2}$ having lowest irrigation level. Whereas, minimum $\left(4.09^{\circ} \mathrm{B}\right) \mathrm{TSS}$ was observed in the treatment $\mathrm{T}_{5}$. This study reveals that TSS goes on decreasing with the increase in irrigation levels and frequencies. The results of the present studies contradict (Gupta et al., 2010), who had reported highest TSS through moderate irrigation level i.e., $80 \%$ evapotranspiration through drip irrigation as compared to $60 \%$ and $100 \%$ evapo-transpiration in capsicum. On the other hand, Birhanu and Tilahun (2010) had observed that total soluble solids content in tomato increases with the increase in stress 
level, while moisture content of fruits decreases.

\subsection{Ascorbic acid ( $\left.\mathrm{mg} 100 \mathrm{~g}^{-1}\right)$}

Ascorbic acid content in the fruits is an important quality parameter from nutritional point of view. A perusal of the data as presented in the Table 2 revealed that different levels and frequencies of irrigation produced significant differences with regards to mean ascorbic acid. Pooled analysis of the data (2010 and 2011) showed that the effect of treatments was significant with maximum contents of $126.19 \mathrm{mg}$ was recorded in the treatment $\mathrm{T}_{6}$. While, minimum (122.63 mg) contents were observed in the treatment $\mathrm{T}_{2}$. It has been noticed that ascorbic acid content goes on increasing with the increase in irrigation level. Similarly, (Gupta et al., 2010) has also reported maximum ascorbic acid content with $100 \%$ evapo-transpiration as compared to $80 \%$ and $60 \%$ trough drip irrigation in capsicum. In the mean while, (Singh et al., 2010) observed higher ascorbic acid content with 0.75 pan evaporation as compared to 0.5 and 1.0 pan evaporation in
2006) were also in the opinion that higher irrigation rates are not recommended in capsicum, because they result in reduced water use efficiency, decrease in yield and increased incidence of soil borne diseases.

\subsection{Water productivity $\left(\mathrm{kg} \mathrm{m}^{-2} \mathrm{~cm}^{-1}\right)$}

In the present investigations, maximum quantity of irrigation water during both the years of study was applied in the treatment $T_{5}$ through 192 irrigations (Table 3). However, treatment $\mathrm{T}_{4}$ with moderate level of irrigation water resulted in maximum yield $\left(12.76 \mathrm{~kg} \mathrm{~m}^{-2}\right)$ with low water productivity of $0.25 \mathrm{~kg} \mathrm{~m}^{-2} \mathrm{~cm}^{-1}$. (Ertek et al., 2007) were of the opinion that low water productivity did not allow to get highest economic yield. In the mean while, maximum water productivity of 0.43 $\mathrm{kg} \mathrm{m}^{-2} \mathrm{~cm}^{-1}$ was recorded in the treatment $\mathrm{T}_{2}$. Greater water productivity and saving of irrigation water in this treatment might be attributed to minimum water loss through deep percolation, run-off, seepage and soil moisture evaporation (Patil and Patil, 2009). The water productivity also decreased

Table 3: Effect of irrigation levels and frequencies on water productivity and soil moisture of capsicum under protected conditions (Pooled data of 2010 and 2011)

\begin{tabular}{|c|c|c|c|c|c|c|}
\hline \multirow[b]{2}{*}{ Treatments } & \multicolumn{4}{|c|}{$\mathrm{WP}\left(\mathrm{kg} \mathrm{m}^{-2} \mathrm{~cm}^{-1}\right)$} & \multicolumn{2}{|c|}{ Soil moisture (\%) } \\
\hline & $\begin{array}{l}\text { No. of } \\
\text { irrigations }\end{array}$ & $\begin{array}{l}\text { Water applied } \\
(\mathrm{cm})\end{array}$ & $\begin{array}{c}\text { Average yield } \\
\left(\mathrm{kg} \mathrm{m}^{-2}\right)\end{array}$ & $\begin{array}{c}\text { WP } \\
\left(\mathrm{kg} \mathrm{m}^{-2} \mathrm{~cm}^{-1}\right)\end{array}$ & $0-7.5(\mathrm{~cm})$ & $7.5-15.0(\mathrm{~cm})$ \\
\hline $\mathrm{T}_{1}$ & 183.50 & 48.17 & 8.75 & 0.18 & 20.70 & 22.82 \\
\hline $\mathrm{T}_{2}$ & 91.00 & 25.04 & 10.79 & 0.43 & 20.67 & 22.67 \\
\hline $\mathrm{T}_{3}$ & 192.50 & 98.54 & 12.48 & 0.13 & 21.74 & 24.75 \\
\hline $\mathrm{T}_{4}$ & 98.50 & 51.54 & 12.76 & 0.25 & 21.71 & 24.72 \\
\hline $\mathrm{T}_{5}$ & 192.00 & 146.29 & 11.92 & 0.08 & 22.17 & 25.18 \\
\hline $\mathrm{T}_{6}$ & 97.50 & 75.42 & 11.53 & 0.16 & 22.05 & 25.12 \\
\hline $\mathrm{T}_{7}$ & 53.00 & 68.54 & 9.38 & 0.14 & 19.23 & 19.28 \\
\hline
\end{tabular}

polyhouse grown capsicum, which contradicts the results of present investigations.

\subsection{Root rot incidence (\%)}

The data recorded on root rot incidence (\%) showed significant differences among various treatments with regards to levels and frequency of irrigation (Table 2). Pooled analysis of data (2010 and 2011) revealed that minimum root rot incidence $(2.76 \%)$ was recorded in the treatment $T_{2}$ as compared to maximum in the treatment $\mathrm{T}_{5}(18.12 \%)$. It has been noticed that incidence of root rot increased at higher irrigation frequency and levels of irrigation. Higher incidence of root rot in the treatment T5 might be attributed to favourable soil moisture for disease development. In line with present findings, Diaz-Perez (2009) has reported that incidence of soil borne diseases (Pythium sp. and Phytophthora capsici) increases with the increase in the frequency and level of irrigation. Similarly, (Simonne et al., with increasing levels and frequencies of irrigation water and lowest water productivity of $0.08 \mathrm{~kg} \mathrm{~m}^{-2} \mathrm{~cm}^{-1}$ was recorded in treatment $\mathrm{T}_{5}$ during both the years of the study. Earlier workers like Costa and Gianquinto (2002), (Ertek et al., 2007; and Sezen et al., 2011) had also reported that water productivity decreases with the increase in irrigation level in capsicum. In contradict to present studies; (Sezen et al., 2011) had observed that water productivity increases with the increase in irrigation frequency. This might be due to the difference in treatment intervals, soil, climatic conditions and protected structure used in the present study.

\subsection{Soil moisture (\%)}

Water management in capsicum is extremely important at all stages of plant development due to its influence on stand establishment, fruit set and quality (Costa and Gianquinto, 2002). For higher yields, an adequate water supply and 
relatively uniform soil moisture is required during total growing period (Sezen et al., 2011). The perusal of pooled data (2010 and 2011) on soil moisture content revealed that the treatment $\mathrm{T}_{5}$ registered maximum per cent soil moisture contents of 22.17 and 25.18 at $0-7.5$ and $7.5-15.0 \mathrm{~cm}$ soil depths, respectively (Table 3 ). In general, it has been noticed that soil moisture content increased with the increase in frequency and level of irrigation. Similarly, Diaz-Perez (2009) has also reported average soil moisture content of $14 \%$ at $166 \%$ ET as compared to $8 \%$ at $33 \%$ ET in capsicum. Moreover, (Sezen et al., 2011) has also observed that soil water contents remained fairly high in high frequency plots as compared to low frequency plots. Further, It was observed that drip irrigation registered higher soil moisture content at both the soil depths as compared to treatment $\mathrm{T}_{7}$ (Farmer's practices), which recorded lower soil moisture contents during both the year. Present findings revealed that both the excess as well as deficiency of water has hampered the crop growth and higher yields were obtained with the treatment $\mathrm{T}_{4}(0.50 \mathrm{~cm}$ irrigation at alternate day) having optimum levels of soil moisture at all the stages of crop growth.

\section{Conclusion}

Treatment with $0.50 \mathrm{~cm}$ of irrigation at alternate day resulted in maximum fruit breadth, average fruit weight, number of fruits per plant, total biomass production and higher economic yield with moderate water productivity. Hence, this may be recommended for commercial cultivation under naturally ventilated polyhouses. However, the treatment with 0.25 $\mathrm{cm}$ of irrigation at alternate day recorded maximum water productivity and total soluble solids with moderate yield and lowest root rot incidence, may be suggested for the high water scare areas for successful cultivation of capsicum under protected conditions.

\section{References}

Akinbile, C.O., Yusoff, M.S., 2011. Growth, yield and water use pattern of chilli pepper under different irrigation scheduling and management. Asian Journal of Agricultural Research, 5(2), 154-163.

Anonymous, 2009. Water requirement of vegetable crops. American Vegetable Grower 26, 92-95.

Anonymous, 2010. Package of practices for vegetable crops. Directorate of Extension Education, Dr. Y.S. Parmar UHF, Nauni, Solan, HP, India, 202.

Birhanu, K., Tilahun, K., 2010. Fruit yield and quality of dripirrigated tomato under deficit irrigation. African Journal of Food, Agriculture Nutrition and Development 10(2), 2139-2151.

Chartzoulakis, K., Drosos, N., Chartzoulakis, K.S., 1997.
Water requirements of greenhouse grown pepper under drip irrigation. Acta Horticulturae 449, 175-180.

Costa, L.D., Gianquinto, G., 2002. Water stress and water table depth influence yield, water use efficiency and nitrogen recovery in bell pepper: Lysimeter studies. Australian Journal of Agricultural Research 53, 201-210.

Dagdelen, N., Yilmaz, E., Sezgin, F., Gurbuz, T., 2004. Effects of water stress at different growth stages on processing pepper (Capsicum annuum cv. Kapija) yield, water use and quality characteristics. Pakistan Journal of Biological Sciences 7(12), 2167-2172.

Diaz-Perez, J.C., 2009. Drip irrigation levels affect plant growth and fruit yield of bell pepper. Proceedings of the 2009 Georgia Water Resources Conference, April 27-29, 2009. University of Georgia.

Ertek, A., Sensoy, S., Gedik, I., Kucukyumuk, C., 2007. Irrigation scheduling for green pepper (Capsicum annuит L.) grown in field conditions by using class-A pan evaporation values. American Eurasian Journal of Agriculture and Environment Sciences 2(4), 349-358.

Ghosal, M.K., Das, R.K., 2012. A study on the cultivation of capsicum in a greenhouse during off-season in warm and humid climate of India. International Journal of Agricultural Sciences 8(1), 220-223.

Gomez, K.A., Gomez, A.A., 1984. Statistical Procedures for Agricultural Research. John Wiley and Sons. Inc., New York, 357-427.

Gupta, A.J., Ahmad, M.F., Bhat, F.N., 2010. Studies on yield, quality, water and fertilizer use efficiency of capsicum under drip irrigation and fertigation. Indian Journal of Horticulture 67(2), 213-218.

Hardeman, T.L., Tabera, H.G., Coxb, D.F., 2000. Trickle irrigation of vegetables: Water conservation without yield reduction. Journal of Vegetable Crop Production 5(2), 23-33.

Hegde, D.M., 1988. Effect of irrigation regimes on growth yield and water use of sweet pepper (Capsicum annuиm L.). Indian Journal of Horticulture 45(3-4), 288-294.

Kurubetta, Y., Patil, A.A., 2009. Performance of coloured capsicum hybrids under different protected structures. Karnataka Journal of Agricultural Sciences 22(5), 1058-1061.

Manna, C.R., Ray, P., 2015. Determination of transplanting time of the capsicum seedlings for yield and profit maximization. International Journal of Bioresource Science 2(2), 71-80.

Masuda, T., Hayashi, K., 1957. Studies on peppers. II. Effects of soil moisture on flowering, fruit setting and maturing of red pepper. Studies from Institute of Horticulture, 
Kayoto 8, 91-98.

Muthukrishnan, C.R., Thangaraj, T., Chatterjee, R., 1986. Chilli and capsicum. In: Bose, T.K., Som, M.G., Vegetable Crops in India. Naya Prokash, Calcutta, 343-366.

Ochigbo, A.A., Haris, G.P., 1989. Effects of film plastic cover on growth and yield of bush tomato grown in a bed system. Journal of Horticultural Sciences 64(1), 61- 68.

Patil, P.P., Patil, V.S., 2009. Effect of mulching with drip irrigation on summer capsicum yield and economics. Indian Journal of Soil Conservation 37(1), 50-54.

Ranganna, S., 1986. Handbook of Analysis and Quality Control for Fruit and Vegetable Products. Tata McGraw Hill Publishing Co., New Delhi, 88-107.

Roopa, M., Kumar, C.T.A., 2014. Seasonal incidence of pests of capsicum in Bangalore conditions of Karnataka, India. Global Journal of agriculture, Biology and Health sciences 3(3), 203-207.

Sezen, S.M., Yazar, A., Tekin, S., Eker, S., Kapur, B., 2011. Yield and quality response of drip irrigated pepper under Mediterranean climatic conditions to various water regimes. African Journal of Biotechnology 10(8),
1329-1339.

Simonne, E.H., Dukes, M.D., Hochmuth, R.C., Studstill, D.W., Avezou, G., Jarry, D., 2006. Scheduling drip irrigation for bell pepper grown with plasticulture. Journal of Plant Nutrition 29(10), 1729-1739.

Singh, K.G., Singh, A., Mahajan, G., 2010. Response of sweet pepper (Capsicum annuum L.) to irrigation and fertigation grown in naturally ventilated polyhouse. Indian Journal of Agricultural Sciences 80(5), 430-432.

Singh, S., Sharda, R., Lubana, P.P.S., Singla, C., 2011. Economic evaluation of drip irrigation system in bell pepper (Capsicum annuит L. var. Grossum). Progressive Horticulture 43(2), 289-293.

Smittle, D.A., Dickens, W.L., Stansell, J.R., 1994. Irrigation regimes affect yield and water use by bell pepper. Journal of American Society for Horticultural Science 119(5), 936-939.

Vox, G., Teitel, M., Pardossi, M., Minuto, A., Tinivella, F., Schettini, E., 2010. Sustainable greenhouse systems. In: Sustainable Agriculture by Salazar A and Rios I (Eds.). Italy: Nova Science Publishers, 1-70. 